\title{
Efficacy of Panchkarma in Amyotrophic Lateral Sclerosis: A Case Study
}

\section{Gusain M and Srivastava AK* \\ Department of Panchkarma, Uttarakhand Ayurved University, India}

*Corresponding author: Alok Kumar Srivastava, Department of Panchkarma, Rishikul Campus, Uttarakhand Ayurved University, India, Tel: +91-9045087121; Email: virgo.alok@gmail.com

\section{Case Report}

Volume 2 Issue 4

Received Date: May 30, 2018

Published Date: June 11, 2018

\section{Abstract}

Amyotrophic lateral sclerosis (ALS) is a progressive degenerative disease of UMN's of corticospinal tract, and the LMN's and is the most devastating of the neurodegenerative disorders. Disease is entirely motor that affects the motor neurons of the cells that control needed voluntary muscle activity such as speaking, skeletal muscle movement, breathing and swallowing while all the sensations, bowel and the bladder remains intact. As the disease progresses, the patient will be paralyzed and eventually dies due to the respiratory arrest. The exact cause and mechanism for its progression is unknown, hence it is difficult to develop an effective treatment for ALS. There is no cure of this disease. A 75 years, male patient, Army retired by occupation came to Panchkarma O.P.D Dept. of Rishikul campus, Haridwar with complaints of weakness in B/L upper and lower limbs more in lower having difficulty in buttoning clothes, opening cap of pen, difficulty in walking, reduced gripping of both hands and mild slurred speech since 8-9mnths. Patient had undergone various Panchkarma procedures. During and after it he got mild relief in symptoms of weakness of upper limbs, improvement in gripping and speech. Panchkarma presents a unique approach of ayurveda with specially designed five procedures of internal purification of the body through the nearest possible route namely. Present case study deals with the case of ALS and its ayurvedic diagnosis and management through one of the procedure known as Vasti (a medicated enema therapy) and Nasya (medicate errhine therapy). As there was no clarity regarding Ayurvedic aspect of MND/ALS, a major diagnostic and management dilemma exists while approaching the case of MND. In Ayurveda, there is difficulty in diagnosis and we consider it like Sarvanga Vata, Avrit Vata and Sama Vata.

Keywords: Amyotrophic Lateral Sclerosis; Panchkarma; Ayurveda; Vata vyadhi 


\section{Journal of Natural \& Ayurvedic Medicine}

Abbreviations: ALS: Amyotrophic lateral sclerosis; RNS: Repititive Nerve Stimulation NCS: Nerve Conduction Study.

\section{Introduction}

Amyotrophic lateral sclerosis (ALS) also known as Lou Gehrig's disease, is a specific disease that causes the death of neurons which control voluntary muscles [1]. Most people who develop ALS are between the ages of 40 and 70 . It is $20 \%$ more common in men than in women. $93 \%$ of patients are Caucasian. Half of all people affected with ALS live at least three or more years after diagnosis. The cause is not known in $90-95 \%$ cases. But probable Causes of ALS are Free radicals, increased levels of glutamate and autoimmune responses. 90 to $95 \%$ of all cases are sporadic forms of ALS. And 5 to $10 \%$ of all cases are familial. At its onset ALS may involve selective loss of function of only upper or lower motor neurons, but ultimately it involves both the categories of motor neurons [2]. Ayurveda is ancient science of life and has various treatment modalities for the ailing humanity. The signs and symptoms of ALS resemble some diseases explained in Ayurveda in Vata vyadhi. Vata is the primal constituent of the living body and is responsible for functions of central, autonomic and peripheral nervous system. It also controls the cognitive and neocognitive functions of the brain and secretion of various chemical neurotransmitters and hormones. It is the urger of all the senses, brings about speech.

\section{वायुस्तंत्रयंत्रधर:....... सर्वैन्द्रियानामउद्योजक:, सर्वेंद्रियानामअभिवोढा, प्रवर्तको वाच.......। (च. सू.१२/८) [3]}

\section{Probable Pathogenesis According to Ayurveda}

Vitiation of Vata can occur by two types either by depletion of Dhatus (body tissue) or due to the obstruction of Vata by another Dhatu, Dosha or Mala, which will result into a disease by undergoing pathology. According to Ayurveda the present case report deals with ALS diagnosed as Kapha Avrit Udaana and Kapha Avrit Vyaana Vata [4]. That means the Udaana Vata (a type of vata responsible for the vocal speech of human) and Vyaana Vata (a type of Vata responsible for the movement or daily routine activities) has been occluded by Kapha Dosha which hampers the normal functioning of Vata.

\section{Case Description}

A 75 years, male patient, Army retired by occupation came to Panchkarma O.P.D Dept of Rishikul campus,
Haridwar with complaints of weakness in B/L upper and lower limbs more in lower, and fasciculation in forearm muscles, mild difficulty in speech with generalized weakness. Patient was having difficulty in doing his regular activities like buttoning clothes, opening of cap of pen, walking and reduced gripping of both hands since 8$9 \mathrm{mnths}$, which was gradually worsening.

According to the Patient he was asymptomatic 8-9 months back. Gradually he developed weakness in both the arms first in the left, then right. Now he is having difficulty in holding the objects, lifting arms. Difficulty to button up shirts and even in opening the cap of pen. Later on reduced gripping of hands and mild slurring of speech developed. He went to many higher centers like CGHS, AIIMS. There he was diagnosed with ALS with Brachial Plexopathy. Later on he developed weakness in B/L lower limbs that causes difficulty in walking. He took various Allopath, Ayurveda, Homeopath and Acupuncture treatment for this problem but didn't get much relieved. The problem worsened and the patient developed stooped posture, muscle wasting and tremors of hands has been developed. Patient is $\mathrm{k} / \mathrm{c} / \mathrm{o}$ Hypertension since $20 \mathrm{yrs}$ and had undergone angioplasty two times also he is having problem of Urine incontinence since 6-7 yrs. Currently he was on medication - Starpress (telmisartan + metoprolol succinate), Urimax (tamsulosin) and Riluzox $(100 \mathrm{mg} /$ day). No family member has suffered with similar problem.

\section{Personal History}

- Addiction: not any, Dietary Habit: vegetarian, Sleeping Habit: Sound, Defecation: normal (2 times a day),

- Micturition: normal (Incontinence of bladder after episode), Thirst: normal (3 litr /day).

On examination patient was found alert ad responding to commands. Higher function was normal. Speech was slurred, increased tears production, unable to shrug off shoulder of both the sides, Sensory reflexes were normal. Motor reflexes - iii) Power: Lt. arm- 1/5, Rt. arm- 1/5, Lt. leg- 5/5, Rt. leg- 5/5, Superficial reflexes were normal. Deep tendon reflexes were diminished at biceps, triceps, supinator, normal at knee and ankle. Stepping gait, postural instability and urine incontinence were found. On Planter reflexes Babinski sign was fond to be $\mathrm{B} / \mathrm{L}$ negative. Fasciculation were found in $b / l$ upper limbs with mini polymyoclonus. Atrophy was present in b/l shoulder, arm, hypothenar muscles. Muscle tone Shoulders (flexors, extensors and adductors - Rt (3), Lt. (3); Elbow (flexors B/L (2), extensors B/L (4); Wrist (flexors B/L (4). Lower limbs bilateral hip movement 


\section{Journal of Natural \& Ayurvedic Medicine}

(grade 4), knee flexors and extensors B/L (4), ankle (B/L (3). Muscle strength/gripping - 0 finger. Kyphosis of cervical spine was present.

Hematological, biochemical, serum calcium and thyroid profile reports were normal. In MRI Cervical Spine Cervical spondylotic changes. C3/C4 \& C4/C5 mild diffuse disc bulges indenting thecal sac and bilateral mild foraminal narrowing. C5/C6 osteophyte complex. In MRI BRAIN - Small old haemorrhage in left basal ganglia. Multiple focal and diffuse arteriosclerotic hyper intensities in subcortical and paraventricular white matter, bilateral basal ganglia and pons. Mild age related cortical atrophy was present. RNS (Repititive Nerve Stimulation) - Post synaptic NMJ disorder. NCS (Nerve Conduction Study)-mild degree of carpal tunnel syndrome on Rt. Side. EMG-F response-normal, H- reflex-absent, SSR - present

\section{Diagnosis According to Ayurveda}

The patient was diagnosed as Kapha Avrita Udana and Kapha Avrita Vyana Vata according to ayurveda. Treatment was aimed to remove Kapha Avarana (occlusion by Kapha Dosha) followed by Vata Shamaka Chikitsa (alleviation of vitiated vata dosha). Various Panchakarma procedures like Udwartana (herbal powder massage), Sarvaanga Abhyanga (full body oil massage), Bashpa Sweda (sudation in steam chamber), Vasti (enema procedures), Shashtika Shali Pinda Sweda (rice bolus massage) and Nasya (Errhine therapy) were implemented which are mentioned in Table 2. Line of treatment was flexible and modified according to the necessity and tolerance of the patient (Table 1).

\begin{tabular}{|c|c|c|c|}
\hline Medicine & Dose & Anupana & Duration \\
\hline Ajmodadi churna & $5 \mathrm{gms}$ twice a day & Lukewarm water & 5 days \\
\hline Ashwagandharishtha & $20 \mathrm{ml}$ twice a day & Add equal amount of water & 15 days \\
\hline Ras Rajeshwar Ras & $250 \mathrm{mg}$ twice a day & Normal water & 1 month \\
\hline Narsingh churna & $5 \mathrm{gm}$ twice a day & Lukewarm milk & 1 month \\
\hline
\end{tabular}

Table1: Drug Intervention (oral).

- Ajmodadi churna ingredients: Powder of Carum Roxburghianum, Embelia Ribes, Plumbago Zeylanica, Cedrus Deodara, Piper Longum, Piper Nigrum, Anethum Sowa, Terminalia Chebula, Zinger Officinale, Argyreia Speciosa and Rock Salt.

- Ashwagandharishtha: fermented decoction of Withania Somnifera.
- Ras rajeshwar rasa: tablet formed from Stychnos Nuxvomica, Withania Somnifera, Commiphora Mukula and Rasa Raja Rasa.

- Narsingh churna: Powder of Asparagus Racemosus, Tribulus Terrestris, Dioscorea Bulbifera, Pueraria Tuberosa, Tinospora Cordifolia, Plumbago Zeylanica, Semicarpus Anacardium, Piper Nigrum, Sesamum Indicum, Zingiber Officinale, Piper Longum, honey bee (Apis Mellifera) and ghee (cow's clarified butter).

\begin{tabular}{|c|c|c|c|}
\hline S. No. & Panchakarma therapy & Drug & Duration \\
\hline \multirow{2}{*}{2} & Udwartana & Ashwagandha churna, Shunthi churna & 5 days \\
\cline { 2 - 4 } 2 & Sarvanga Abhyanga & Mahanarayana taila & 15 days \\
\cline { 2 - 4 } & Bashpa sweda & Dashamoola kashayam & 15 days \\
\hline \multirow{2}{*}{3} & Matra vasti & Mahanarayana taila (50ml) & 15 days \\
\cline { 2 - 4 } & Nasya & Ksheerabala 101 taila & 10 days \\
\hline \multirow{3}{*}{4} & Shashtika Shali Pinda Sweda & Shashti rice, Godugdha, Balamula kashaya & 10 days \\
\cline { 2 - 4 } & Sarvanga Abhyanga & Mahanarayana taila & 15 days \\
\cline { 2 - 4 } & Bashpa sweda & Dashamoola kashayam & 15 days \\
\hline
\end{tabular}

Table 2: Panchakarma Intervention. 


\section{Journal of Natural \& Ayurvedic Medicine}

\section{Discussion}

Although there is no precise equivalent for MND in Ayurveda, MND can be considered as 'VATA' predominant disease. Most of the signs \& symptoms of MND like fasciculations (Gaatra kampa), cramps (Bheda, Toda), wasting, weakness (balopghata), spasticity (Parvanam Stambha) etc. match that of the classical signs \& symptoms of Vata derangement described in Ayurveda [5].

Here in this case shows predominant involvement of both Vata and Kapha in Samprapti (pathogenesis). The aggravated Kapha causes Avarana (obstruction), leads to Vata Prakopa (aggravation of Vata) and produces MND. The clinical picture of MND resembles with 'Kapha Avrita Udaana and Vyaana Vata' [6]. The line of treatment was planned according to that.

Patient's complaints like, Kaarshya (emaciation), Gaatra kampa (tremors), Sphurana (fasciculations) and Balopaghata (fatigue) symptoms are similar to Vata Prakopa Lakshana's and symptoms like, Gaatra Guruta (heaviness of body) are the Kapha Prakopa Lakshana's; Stabdhata (rigidity/spasticity), Swara Bhedha / Vaakgraha (speech difficulties), Gati Vaishamya (difficulty in walking or movements) etc; Avrita Vata Lakshana's were also seen in the patient $[7,8]$.

Initially to remove Kapha Avarana, Rukshan swedan (Udwartanam) with Ashwagandha churna and Shunthi churna was done along with internal medicines like Ajmodadi churna were administered to remove Ama (obstructions due to toxins). Ashwagandha churna has balya property and Shunthi Churna was added due to its irritant property, it stimulates the dermatomes and the nerve endings in the periphery. After 5 days of Udwartana, patient felt lightness in body and appetite improved. Then pure Vata Chikitsa like Sarvanga Snehana by Mahanarayana taila and Bashpa Swedana by Dashamoola kashayam was done along with Matra Vasti (rectal enema) with Mahanarayana taila for 15 days. Both the internal as well as external application of Sneha will do the Vata Shamana. Internal medicine like Ashwagandharishtha was administered as appetizer and for strengthening. After which there was small improvement in weakness of hands and power was 2.5/5 bilaterally. After that Shashtika Shali Pinda Sweda and Nasya was administered for 10 days, mild improvement in speech was observed. Shashtika Shali Pinda Sweda will give strength to the muscles and improves the peripheral vascular circulation, while Nasya will increases the blood circulation and stimulates the nervous system. At last
Sarvanga Abhyanga (massage) by Mahanarayana taila and Bashpa Swedana by Dashamoola kashayam was done along with Matra Vasti (rectal enema) with Mahanarayana taila for 15 days.

To tackle speech difficulty, Nasya was administered with Ksheerabala 101 Taila. Ras Rajeshwar Ras and Narsingh churna were prescribed to deals with muscle wasting, fasciculations, tremors and generalized weakness. At the time of discharge internal medicines were prescribed to tackle Vata Dosha were Ras Rajeshwar Ras $250 \mathrm{mg}$ twice a day, Narsingh churna [9] 5gm twice a day and Ashwagandharishtha $20 \mathrm{ml}$ twice a day.

\section{Results}

Before starting treatment, total score of ALSFRS-R was 20 , at the time of discharge the score was 25. Patient showed good improvement in items like speech, holding objects, walking and generalized weakness. Patient felt good relief in generalized weakness with Ksheerabala101 and other Panchkarma therapies. At the time of discharge, the patient's gait was improved; felt energetic, spasticity of both upper and lower limbs decreased with overall improvement in general condition. There was no improvement in fine motor movements of both hands.

\section{Conclusion}

The Ayurvedic diagnosis of this case, Motor Neuron Disease can be as Kaphavrita Udaana and Vyana Vata. Here foremost treatment plan was to remove the Avarana of Kapha and Ama internally by Ajmodadi Churna and externally by Udwartanam. Then after Vata Nashaka and Balya Chikitsa were implemented by Abhyanga, Swedana and Nasya therapies which were found to be beneficial in improving speech difficulties and tackling muscle weakness. Panchakarma procedures like Sarvanga Abhyanga, Bashpa Sweda and Vasti are found to tackle with spasticity of limbs and to arrest the progression of ALS. Further long term follow up studies on large sample are required to substantiate the above claims. Hence, more research is needed in this aspect.

\section{References}

1. Amyotrophic lateral sclerosis.

2. Harrison's Principles of Internal Medicines. pp: 2361.

3. Charaka (2011) Charak Samhita, Kashinath Shastri and Gorakhnath Chaturvedi (Eds.), Chaukhambha Bharti Academy, Varanasi, pp: 246. 


\section{Journal of Natural \& Ayurvedic Medicine}

4. Charaka (2011) Charak Samhita, Kashinath Shastri and Gorakhnath Chaturvedi (Eds.), Chikitsa Sthana chapter 28, Chaukhambha Bharti Academy, Varanasi, pp: 815.

5. Charaka (2011) Charak Samhita, Kashinath Shastri and Gorakhnath Chaturvedi (Eds.), Chikitsa Sthana chapter 28, Chaukhambha Bharti Academy, Varanasi, pp: 780 .

6. Charaka (2011) Charak Samhita, Kashinath Shastri and Gorakhnath Chaturvedi (Eds.), Chikitsa Sthana chapter 28, Chaukhambha Bharti Academy, Varanasi, pp: 814-815.
7. Vriddha vagbhata, Ashtanga sangraha, Sutra sthana (2008) Doshaadi vigyaneeyam adhyaya, 19/5, Shiv prasad Sharma (Ed.), Varanasi: Chaukhamba sanskrit series office, pp: 149.

8. Vagbhata, Ashtanga hridaya, Sutra sthana, (2008) Doshaadi vigyaneeyam adhyaya, 13/26-28, (Ed.), Shiv prasad Sharma. Varanasi: Chaukhamba sanskrit series office, pp: 149.

9. Chakrdatta of Sri Chakrapanidatta (2005) Ramnath Dwivedi, Chapter 67/15-24. Chaukhamba Sanskrit Sansthana, Varanasi, pp: 432-433. 